\title{
Indonesian Legal Reform Based on Pancasila
}

\author{
Muhammad Muladi ${ }^{1}$, Suparno $^{2}$ \\ Universitas Borobudur Jakarta ${ }^{1,2}$ \\ \{muhammadunboro@gmail.com¹,suparno@borobudur.ac.id² $\}$
}

\begin{abstract}
Sovereignty is the essence of independence, namely the right of every nation to determine its destiny and determine what is best for its nation. Indonesia has been independent for 75 years, but not yet independent in the true sense, especially independence in the field of law. Of course, this is very concerning and is a serious issue that must immediately reform Indonesian law. The importance of legal reform is a form of state sovereignty in the field of law. Besides, Pancasila in this regard as rechtsidee has not been fully positioned as a legal ideal. Reform is carried out by reaffirming a return to the ideological path, namely through the formation of Indonesian law and legal system, which is grounded and based on the values of Pancasila as the state philosophy, ideology, legal ideals, and the source of all sources of Indonesian law. Pancasila has a position as the state's fundamental norm (staatsfundamentalnorm) which is the highest norm in the Indonesian legal norm system. The placement of Pancasila as the source of all sources of state law has the consequence that all laws and regulations are sourced and must not conflict with the values of Pancasila. Through this legal reform, it is expected that it can provide a guarantee, certainty, and true justice for all Indonesian people.
\end{abstract}

Keywords: legal reform; Pancasila

\section{Introduction}

Every August 17, the Indonesian people celebrate Independence Day. However, in this case, it is not just a "celebration of independence", but more than that, namely as an event while evaluating the extent to which the spirit of independence has been in filling independence through various fields of development in Indonesia. Development is very broad in scope, including, among other things, political, economic, social, cultural, defense, technology, and so on, including legal development. But unfortunately, until now we have not been fully independent in the field of law.

75 years of independence of Indonesia, of course as an independent country Indonesia should have its law and legal system. However, until now Indonesia still does not have its law and legal system. Indonesia in the life of the nation and state in the field of law is still constrained by the legacy of colonial law products that still exist in the arena of state life in Indonesia. At this time, the law in Indonesia has three major problems that must be reformed, namely; problems of improving the quality of law enforcement based on concrete issues (law enforcement), issues of development/renewal of SHN (National Law System), and the development of multi-complex globalization problems, problems of internationalization of 
law, globalization or transnationalization of crime, and the problem of Hitech/cybercrime that continues to grow. [1]

Legal renewal or development is essentially renewal / sustainable development (sustainable reform / sustainable development). [2] In the renewal of legal development, it is always related to the development of sustainable community development / sustainable development of scientific activities or activities and the development of philosophical thoughts / basic ideas / intellectual conceptions.

Currently, Indonesia still applies legal pluralism and a legal system. There are at least four legal systems in place, namely the customary law system, the Islamic legal system, the "civil law" system, and the "common law" system. The lack of independence of Indonesia in the field of law is of course very concerning and is a serious problem that must be carried out immediately by reforming Indonesian law through the formation of Indonesian law and legal system, which must be based and based on the values of life and Indonesian culture, namely Pancasila as a national life philosophy and the basis of the state. Thus, the legal order and legal system in Indonesia must refer to the legal ideals (rechtsidee) of Pancasila. [3]

Having to refer to the ideals of Pancasila law is a consequence of making Pancasila the basis of the philosophy of the nation and state, which means that Pancasila must be the basis that animates every step of the life of the nation and state of Indonesia. Therefore, the importance of developing Indonesian national law, which is implemented through legal reform as a whole. Renewal is mainly caused by the urgent need for a law with the spirit of Pancasila.

Barda Nawawi Arief said that the effort to reform the national law does not mean that it has never been done. The reforms that have been made are only done partially, for example by inserting articles into the Criminal Code or declaring certain articles in the Criminal Code invalid. The current Indonesian Criminal Code is not integrated with the values of Pancasila. [4] He further said that the Dutch legacy KUHP does not contain humanitarian and justice principles, but only legality principles. Therefore. the Criminal Code cannot forgive. For example, a light crime of taking cotton leftover from the harvest, which can be included in Article 362, even 363. [5]

Because the applicable law is still a legacy of Dutch colonialists, in the implementation of the justice system, both criminal and civil, in guarding law enforcement, it is still not optimal in providing legal certainty and increasing public trust, due to the absence of humanitarianism and justice, which of course is detrimental to seekers. justice.

The importance of reforming Indonesian law, because Pancasila in this case as rechtsidee has not been fully positioned as a legal ideal that directs laws or legislative products under it to fulfill the substantive justice aspired by society. Substantive justice is becoming more complicated for searchers to obtain or feel due to its juridical products which are indeed "dry" from the true substance of justice. Based on the explanation above, it is important to examine the reform of Indonesian law as an implementation of the development of national law. Renewal is a necessity that must be realized in the development of Indonesian national law.

\section{Research Problem}

According to the background, the problem can be identified and formulated into a research problem as below: How is the Indonesian legal reformation based on Pancasila?

\section{Research Method}


This research is a normative legal research, namely doctrinal legal research or theoretical legal research. It's known as normative legal research or library research, [6] which means that the research is based on the library sources to discuss about the problems that has been formulated or which researched is the law of theoretical or normative aspect. It is using philosophy approach, which is an approach that view the law (Pancasila) as an ideal value attribute that should be a reference towards all legal formation, regulation, and operation.

\section{Discussion}

It must be admitted that there are still many laws and regulations currently in effect in Indonesia which originate from the Dutch East Indies colonial period which are not following Pancasila values. As has been stated in the previous explanation, one example is the Criminal Code which is a legacy of the Netherlands which is still used in the administration of criminal law in Indonesia.

To note that the Criminal Code (WvS) inherited from the Dutch East Indies era originated from a continental legal system/family ("Civil Law System") or according to Rene David it was called "the Romano-Germanic family". "Civil Law System" or "the Romano-Germanic family" is influenced by teachings that emphasize the notion of "individualism, liberalism and individual rights". [7] This means that the current Criminal Code in Indonesia was not built based on what is contained in Pancasila and the 1945 Constitution of the Republic of Indonesia.

Even Piepers stated "Met die Code Penal (read W.v.S.Ned.) Ging het als een broek die eerst door vader wordt gedragen, and overgaat op den oudsten en vervolgens met een lap er op, op den tweede zoon". Free meaning: "Code Penal (read the Criminal Code) is like a pair of pants that used to be worn by the father, then transferred to the eldest son and then with a patch of a piece of cloth passed on to the second child". This statement becomes reasonable because it can be said that the Criminal Code is also from France and not only the Netherlands. After all, the Netherlands in essence took over from France, namely the Penal Code c.q. W.v.S.Ned., Where France had colonized the Netherlands. [8] This statement implies that we are still wearing (the law) clothes that were used by the father (the Netherlands), which were then used again by the children (Indonesia), and then continued from era to era until the present reformation era. Therefore, the agenda of legal reform is important and inevitable.

Efforts to reform the law have been echoed since the beginning of independence. In his speech at the Gadjah Mada University Anniversary in 1947, Supomo stated that "the changes that will occur in our country as a result of the realization of the formulation of a new economic order, the ideals of industrialization, expansion of trade relations with foreign countries will require us to carry out legal reform". [9]

Soewandi stated that Supomo had warned us that legal reform was one of the important tasks that must be carried out by the Indonesian nation after independence. This legal reform was seen by him as a necessity generated by the changes that occurred in the life of Indonesian society from a colonial society to a society of an independent nation. From the point of view of constitutional changes; legal reform is a must. [10] 
Furthermore, Soewandi said that Indonesia cannot avoid the obligation to also create its national law, not only to continue the legacy of the past that the basics have completely changed from the era in which we live now. [11]

If we go back in history, in fact, the effort to consciously reform the law has been made by the Government of Indonesia with the establishment of the National Law Enforcement Agency (LPHN) on March 30, 1958, based on the decision of the President of the Republic of Indonesia No. 107 of 1958 and placed directly under the Prime Minister.

LPHN's task at that time was to assist the Government to achieve a national constitution by making various efforts which include the preparation of legislation under the state and interests of the state and the people based on the 1945 Constitution, the proposed legislation of the Dutch East Indies amended or revoked, translation and standardization of legal terms. [12] This institution was later changed to the National Law Development Agency (BPHN) in 1974 based on Presidential Decree No. 45 of 1974. BPHN held its position under the Ministry of Justice with the task of legal reform and national law enforcement.

In addition to the indications contained in the Outlines of State Policy from 1973 to the end of the New Order era, it can be seen that Indonesia has consciously tried and is in the process towards legal reform as part of legal development efforts directed at the formation of an administrative system. new national law. However, until now, the efforts to reform the law massively and comprehensively have never been carried out, because of the many obstacles, especially the lack of "political will and morale" for certain groups, especially vulnerable groups of people who will be exposed to legal problems if the reform occurs and if law enforcement is based on Pancasila purely and consistently, it is feared that it will become the fruit of Simalakama.

Legal reform is an absolute demand from development in the legal sector of countries in the world, such as Indonesia. Economic globalization and advances in information technology have changed the ways of life and communication between nations, demanding that the laws of each country conform to current legal needs. Here the importance of Pancasila values that must underlie this renewal. As we all know that Pancasila is the foundation of national and state life. As the basis for the life of the nation and state, Pancasila has four positions, namely the state philosophy, ideology, legal ideals, and the source of all sources of Indonesian law.

Pancasila is the basic norm of the Indonesian state (grundnorm) and is also the ideal of Indonesian state law (rechtsidee) as a normative and constitutive belief framework. It is normative because it functions as an ideal base and prerequisite that underlies any positive law, and is constitutive because it directs the law to the goals to be achieved. In the next stage, Pancasila becomes the principal principle of the state's fundamental principle of "staatsfundamentalnorm" and is included in the Preamble to the 1945 Constitution (UUD 1945).

Pancasila can be said to have a position as the fundamental norm of the state (staatsfundamentalnorm) which is the basis and source of the basic rules of the state or the basic rules of the state, namely the Articles or the body of the 1945 Constitution, [13] and is the basic foundation of its philosophical foundation which contains basic principles for further country settings. [14] The position of Pancasila as a fundamental norm is the grand design of a society and a new life in Indonesia. [15]

In terms of being a state philosophy, Soerjanto Poespowardojo explained that Pancasila is a system of belief that has a strong power to move society. In socio-cultural terms, Pancasila has the value of fighting for independence, so in other words, Pancasila has a paradigm of freedom. [16] He further said that with the content of the paradigm of freedom contained in Pancasila, if the law always refers to Pancasila, the law that is formed will have an 
emancipatory color. The law will free humans from limitations and fetters. Pancasila is a solution to reforming Indonesian law.

As a source of law, the assertion that Pancasila as a source of law has been legitimized by several provisions, namely MPRS Decree No. XX / MPRS / 1966 (in conjunction with the MPR Decree No. V / MPR / 1973, in conjunction with the MPR Decree No. IX / MPR / 1978) concerning the DPR-GR Memorandum regarding the Sources of Order of RI Law and the Order of RI Legislation and MPR Decree No. III / MPR / 2000 concerning Legal Sources and the Order of Legislation. Then after the reformation, Pancasila was again confirmed by Law Number 10 of 2004 which was later revised again by Law No. 12 of 2011 concerning the Formation of Legislative Regulations.

Law No. 12 of 2011 concerning the Formation of Legislative Regulations, states "Pancasila is the source of all sources of state law". [17] The explanation of this Article explains that the placement of Pancasila as the source of all sources of state law is under the fourth paragraph of the Preamble to the 1945 Constitution of the Republic of Indonesia, namely Almighty Godliness, Just and civilized humanity, Indonesian unity, democracy led by wisdom in Deliberation / Representation, and social justice for all Indonesian people. [18]

As the basis of the state, Pancasila is the basic law of the state where everything related to the constitutional life of the Republic of Indonesia must be based on Pancasila. This implies that all regulations in force in the Republic of Indonesia must originate from Pancasila. In other words, Pancasila is the source of all sources of law for the Indonesian nation and state. Therefore, all acts of power or force in society must be based on legal regulations originating from Pancasila. [19] The placement of Pancasila as the source of all sources of state law has the consequence that all statutory regulations are sourced and must not conflict with the values of Pancasila. Besides, Pancasila, which is the basic norm of the state, is the highest norm in the Indonesian legal norm system and as a basic norm which is the hanger or source of all sources for the norms under it. [20]

Ismail Saleh said that if you want to form and implement legal norms that function to regulate the relationship between a person and each other, as well as between a person and society and country, then you must always place Pancasila as the eye of our conscience. [21] He further stated that Pancasila is not only a legal ideal but also a basic norm of the state. Therefore Pancasila, apart from serving as a guide and guide for the operation of the entire national legal system, is also the highest legal norm, where all state and social norms are linked.

Pancasila as the basis of the state is the source of all sources of law that provides legal guidance and overcomes all laws and regulations. In such a position, the Preamble of the 1945 Constitution and the Pancasila it contains are fundamental norms or principles of fundamental state principles and cannot be changed through the law unless changes are made to the Indonesian identity born in 1945. [22]

By holding Pancasila as the highest source of law and an orderly source of law; as basic values, instrumental values, and practice values; as well as the concretization of divine values, human values, unity values, social values, and social justice values show the strong position of Pancasila. To make the articles, the laws that will be regulated, have ideals, initiative, and a sense of Pancasila, then legal politics is needed to become a catalyst for the idealization of Pancasila. This is because with the politics of law, the noble values of Pancasila principles can be explained or then implemented by the blood, spirit, and breath of Pancasila in the laws they will regulate so that the new law becomes an integral part and does not contradict its regulations with the atmosphere and positive spirit of Pancasila. That is, the newly formed law will be in line with the will and purity of good or positive intentions of Pancasila. [23] 
From the explanation above, it can be seen from the philosophical aspect of the entire Indonesian legal system that it cannot be separated from the view that Pancasila is a Philosophical Grondslag (Grundnorm). [24] This proves the nobility and importance of Pancasila as the state ideology so that it comes to the aspect of the formation or development of the legal system, Pancasila is used as the foundation which is the goal of reforming Indonesian law.

\section{Conclusion and Suggestion}

\subsection{Conclusion}

The importance of legal reform, because Pancasila as rechtsidee has not been entirely positioned as a legal ideal. The reform is intended at making Indonesian law based on and based on the values of Pancasila as the state philosophy, ideology, legal ideals, and the source of all sources of Indonesian law. As a fundamental norm of the state (staatsfundamentalnorm), Pancasila is the highest norm in the legal system of Indonesia. Likewise, Pancasila as the source of all sources of state law which brings consequences for all laws and regulations must be sourced and must not conflict with the values of Pancasila.

\subsection{Suggestion}

The position of Pancasila as the fundamental norms or principles of the fundamental principles of the state requires that Pancasila live in reality, not only in mind. Not only rhetoric or verbalism but in every action in the life of the nation and state. Besides, Pancasila must be the spirit that underlies the formation of national law.

\section{References}

[1][2] Arief, Barda Nawawi.: Pembangunan Sistem Hukum Nasional Indonesia. Online Article. Retrieved from https://bardanawawi. wordpress.com/2009/12/24/38/

[3] Prasetyo, Teguh.: Hukum dan Sistem Hukum Berdasarkan Pancasila. Media Perkasa, Yogyakarta (2013).

[4] [5] Arief, Barda Nawawi.: Seminar "Urgensi Perwujudan Nilai-Nilai Pancasila Dalam Kerangka Pembaruan Hukum”. Semarang, 19 November 2019. Retrieved from file://C:/Users/User/Documents/Prof\%20Barda_\%20KUHP\%20lama $\% 20$ belum\%20terintegrasi\%20nilai-nilai\%20Pancasila\%2020ANTARA\%20News.html

[6] Sutrisno.: Metode Penelitian Research. Cetakan 1, Yayasan Penerbit Fakultas Psikologi UGM, Yogyakarta, 1997.

[7] Arief, Barda Nawawi.: Beberapa Aspek Kebijakan Penegakan dan Pengembangan Hukum Pidana. PT. Citra Aditya Bakti, Bandung (1998).

[8] Sahetapy, J.E.: Reformasi Hukum Harus Mengejawantahkan Pancasila. Bunga Rampai: Dialektika Pembaruan Sistem Hukum Indonesia. Sekretariat Jenderal Komisi Yudisial, Jakarta (2012).

[9] Supomo, R.: Lihat Bab-Bab Tentang Hukum Adat. pp. 20 (1963) 
[10][11] Mr. Soewandi.: Ceramah di hadapan Perhimpunan Ahli Hukum Indonesia dan Persatuan Hukum Indonesia. Jakarta (1955).

[12] Sejarah Berdirinya Badan Pembinaan Hukum Nasional. Article. Retrieved from https://bphn. go.id/readinfo/main_history\#: $\sim:$ text $=$ Sejarah\%20Berdirinya\%20Badan\%20Pembinaan\% $20 \mathrm{Hukum} \% 20$ Nasional\&text $=$ Pertamakali\%20didirikan\%20tanggal\%2030\%20M

[13] [20]Attamimi, A. Hamid. S.: Disertasi "Peranan Keputusan Presiden Republik Indonesia Dalam Menyelenggarakan Pemerintahan Negara, Suatu Studi Analisis Mengenai Keputusan Presiden Yang Berfungsi Pengaturan Dalam Kurun Waktu Pelita I- Pelita IV. Program Doktor Fakultas Pasca Sarjana. Universitas Indonesia, Jakarta (1990).

[14] Soeprapto, Maria Farida Indrati.: Ilmu Perundang-undangan: Dasar-dasar dan Pembentukannya. Kanisius, Yogyakarta (1998).

[15] Rahardjo, Satjipto.: Paradigma Ilmu Hukum. Citra Aditya Bhakti, Bandung (1989).

[16] Soerjanto Poespowardojo, Pancasila Solusi Ampuh Pembaharuan Hukum. Retrieved from https://www.hukumonline. com/berita/baca/ hol15875/pancasila-solusi-ampuhpembaharuan-hukum?page $=2$

[17] [18]Undang-Undang Republik Indonesia Nomor 12 Tahun 2011 tentang Pembentukan Peraturan Perundang-Undangan.

[19] Darmodiharjo, Darji.: Orientasi Singkat Pancasila. Santiaji Pancasila Suatu Tinjauan Filosofis, Historis dan Yuridis Konstitusional. Usaha Nasional, Surabaya (1991).

[21] Saleh, Ismail.: Kebijaksanaan dan Strategi Pembangunan dan Pembinaan Hukum Nasional, Beserta Implementasinya. Departemen Kehakiman Republik Indonesia, Jakarta (1987).

[22] Hidayat, Arief.: Negara Hukum Berwatak Pancasila. Article. Retrieved from https://mkri.id/public/content/infoumum/artikel/pdf/artikel_15_03_arief_hidayat.pdf

[23] Riyanto, Agus.: Hidupnya Nilai-Nilai Pancasila Dalam Pembentukan UndangUndang. Retrieved from https://business-law.binus.ac.id/2019/01/29/hidupnya-nilainilai-pancasila-dalam-pembentukan-perundang-undangan/

[24] Mahfud MD.: Pancasila Sebagai Tonggak Konvergensi Pluralitas Bangsa. Sarasehan Nasional 2011 tentang "Implementasi Nilai-Nilai Pancasila Dalam Menegakkan Konstitusionalisme Indonesia”. UGM dan MKRI, Yogyakarta dan Jakarta (2011). 